\title{
Comparison of Telework in the Czech Republic and Poland and Slovakia with Respect to the Gender
}

\author{
Jaroslav VRCHOTA, Zuzana FRANTÍKOVA, Miroslava VLČKOVÁ \\ University of South Bohemia, České Budějovice, Czech Republic \\ \{vrchota, frantikova, vlckova\} @ef.jcu.cz
}

\begin{abstract}
Home-based telework can bring new excellent quality workers to a company searching for working powers under the situation that there is an economic growth and the unemployment rate is very low. New young workers often seek for a work-life balance and the offer of a home-based telework may be a sought-after requirement from the employee's part. At the same time, it can help to reduce company costs in certain situations, such as the costs relating to the creation of a new job and overhead costs. In the context of the increasing demand for labor and the gradual growth of the interest in part-time work, the active search for this possibility of work is mainly found among families with children under 15 years of age. The accessions of small and medium sized enterprises in the EU member states such as Czech Republic, Slovakia, and Poland are not uniform, which is reflected in the frequency of the use of telework by individual employees on the one hand and the possibility of telework on the part of the employers. The aim of the paper is to compare the approaches of the chosen countries such as Slovakia, Poland, to the approach in the Czech Republic and to the average values within the EU using the EUROSTAT data 2017. The comparison is carried out according to the frequency of use (usually, sometimes and never) and according to the selected statistical methods with respect to the gender in the above-mentioned countries.
\end{abstract}

Keywords: Telework, Teleworking, Gender, Work-life Balance.

\section{$1 \quad$ Introduction}

In accordance with the European Trade Union Confederation, telework is defined as a form of organizing and/or performing work, using information technology, where work, which could also be performed at the employers' premises, is carried out away from those premises on a regular basis [16]. Telework as a concept was first introduced as telecommuting by Jack Nilles [18]. Telework is often defined as a way of work where information communication technology (ICT) enables employees' access to work remotely, usually from home [21, 22]. Increased flexibility supported by the development of IT technology and information society has contributed to the spread of the telework phenomenon [6].

Speaking about the gender there are two approaches regarding the telework and its influence on women: the "new opportunities for flexibility model" and the 
"exploitation model" [15]. The first mentioned approach is supported by Huws [15] claiming that telework enables the better management of life and family thanks to the flexibility; by Dooley [8] arguing that the possibility of telework gives freedom to those who are limited in their work by childcare responsibilities; or by Silver [20] envisaging that the spatial closeness of work and home would break the traditional separation of household roles, which ends up in bigger participation of men in household chores. The latter mentioned model as it is expressed in the title, prompts the disadvantages of telework claimed by Haddon and Silverstone [12] saying that telework is an exploitation of women by both paid work, and the domestic burden of responsibility or by Silver [20] declaring that a home-based telework is an employment that leads to women being exploited and isolated socially, subject to demands from both family and employer, subject to control of their husbands [13, 14].

According to the approaches mentioned in the literature it is obvious that telework is not suitable for everybody and it has its pros and cons. The focus of the paper is to compare telework in the Czech Republic, Slovakia and Poland from the perspective of its frequency and gender. Before to do so, there is a brief survey of telework legal definitions in the chosen countries.

In the Czech Republic, telework is regulated in Section 317 of Act No. 262/2006 $\mathrm{Sb}$., the Labor Code. It is defined as the regime of work of an employee who does not work at the employer's place of work but, under the agreed conditions and who performs a negotiated job during the working hours he/she plans. Sections regarding working hours, overtime, compensation of wages, spare time off in case of overtime and compensation of wages in case of some personal obstacles at the employee's side cannot be applied in case of telework [2,19]. On the other hand, employers should compensate the costs paid by the distant/home employees, however this is regulated implicitly and that's why most employers do not keep the regulation and do not compensate the costs employees pay by doing their work from home. Therefore, the new proposal of the amendment of Labor Code counts with the implementation of new regulation consisting in the specification of the employers' duty to compensate the costs arisen on employee's side.

Regarding the data featuring the usage of telework of the Czech Republic and Slovakia we would presume that the legal regulation would be rather the same. Section 52 of the Labor Code [3, 4] first speaks about homework defining it as "the employment relationship of an employee who performs work for an employer at home or at another agreed place, pursuant to conditions agreed in the employment contract" or about telework defining it as "the employment relationship of an employee the teleworker as a person who performs work for an employer at home or at another agreed place, pursuant to conditions agreed in the employment contract, using information technology within the working time arranged by himself/herself." Same as in case of the Czech regulation sections regarding working hours, overtime, compensation of wages, spare time off in case of overtime and compensation of wages in case of some personal obstacles at the employee's side cannot be applied in case of telework. 
To summarize it up, the legal regulation of telework in the Czech Republic and in Slovakia is the same, however, the Slovak regulation does distinguish in the regulation home work from telework and in case of telework it does emphasize the use of information technology and similarly to the Czech Republic, it emphasizes the freedom regarding the working hours at the employee's side.

In Poland the telework is defined in the Polish Labor Code. The Polish Labor Code (Kodeks Pracy) in article $675 \S 1$ states that "the work may be carried out regularly outside the employer's office using electronic means of communication within the meaning of the rules on electronic provision of services (telework)." $\S 2$ of the article then states that "a teleworker is an employee who carries out work under the conditions of $\S 1$ and delivers the employer's results of his work mainly by means of electronic means of communication." Telework is a normal employment relation that is why the legal regulation is normally applied. The characteristics of telework that distinguish this form of organization and performance from the typical form of employment are: the regularity of the work performed under the conditions of telework, the performance of work outside the employer's workplace, the use of electronic means of communication in the sense of the regulations on electronic provision of services and the transfer of the results of the work by employers mainly by electronic means of communication. Unlike the Czech and Slovak legal regulation of telework, in the Polish legal regulation more than flexible working hours the regularity of telework performance is emphasized as a defining feature of the telework.

\section{Methodology}

Labor market statistics, including telework analyzes, are the priority points of many European Union policies. Telework statistics can be used for a range of analyzes, both macroeconomic, if we see work as one of the factors of production, as well as for analysis of productivity, or competitiveness in the labor market. Analyzes can also be carried out from the point of view of social aspects related to diverse ways of employing workers.

The aim of the paper is to analyze the use of telework within the Czech Republic, Poland and Slovakia. The main target is the comparison of the use of telework with respect to the gender and frequency.

The data tested for further analysis were obtained using publicly available Eurostat data [9]. The comparison was based on several aspects, with the basic division being the use of telework in the individual countries of the European Union, the use of telework by gender (men, women) and the frequency of use (usually, sometimes, never). The survey was attended only by employed people aged 15-64. The comparison was made using the data from the period 2007-2016. The newer data were not available at the date of analysis.

As regards the statistical methods used, the t-test was used for the difference test. The zero hypothesis H0 was set that both groups are equal over against HA, where the two samples are different. 
Test data were obtained using publicly available EUROSTAT [9] data, compared to data for the period 2007 to 2016.

In the statistical comparison of the use of telework, a t-test for a random sample from a two-dimensional layout was used for research purposes, with $n \geq 2[5,10]$. Here we denote $\mu=\mu_{1}-\mu_{2}$ and introduce the difference random sample $Z_{1}=X_{1}-Y_{1}$, $\ldots, Z_{n}=X_{n}-Y_{n}$ whose sample mean and sample variance are $[11,1]$ :

$$
\begin{gathered}
M=\frac{1}{n} \sum_{i=1}^{n} . Z_{i} \\
S^{2}=\frac{1}{n-1} \sum_{i=1}^{n}\left(Z_{i}-M\right)^{2}
\end{gathered}
$$

Statistically, it has always been tested at a significance level of 0.05 where zero hypothesis $H_{0}: \mu_{1}-\mu_{2}=0$ against alternative hypothesis $H_{A}: \mu_{1}-\mu_{2} \neq 0$.

Before testing the hypotheses, the tests of both dispersions of both samples were always performed using the F-test. The calculation is based on the difference between the means of the two samples, the variability of the observed quantity and the size of the two samples. This test statistics is distributed according to Student t-distribution with $n_{1}+n_{2}-2$ degrees of freedom [17]. The degrees of freedom are a t-distribution parameter. Using the Statistica software, we find the exact p-value. This probability corresponds to the probability of occurrence of such or an even more extreme value of the test criterion $t$ assuming the validity of the zero hypothesis. If it is less than 0.05 , we reject the zero hypothesis. This means that the probability that the observed differences occur only by chance is less than $5 \%$. The classical two-sample t-test, in addition to the normal distribution of the observed variable, also assumes that variances are the same in both groups. This assumption is tested by sample estimates of the standard deviations $s_{1}$ and $s_{2}$ by the F-test [7, 23].

\section{Results}

The aim of the paper is to compare the use of telework by men and women in the categories of sometimes, usually and never in the Czech Republic, Poland and Slovakia.

In the first instance, the use of telework by men was tested in the chosen countries. As it is shown in Figure 1 below, the statistical difference between the Czech Republic and Poland was in all categories: sometimes ( $p$-value 0.0000$)$, usually ( $p$-value $0.0001)$ and never ( $p$-value 0.0000). Similarly, $H_{0}$ was rejected in the category of usually between Slovakia and the Czech Republic where the $p$-value is 0.0017. In all these cases the $p$-value is below the alpha of 0.05 . 
Table 1. Men comparison in Poland, Czech and Slovakia.

\begin{tabular}{llllllll}
\hline & $\begin{array}{l}\text { Mean } \\
\text { group 1 }\end{array}$ & $\begin{array}{l}\text { Mean } \\
\text { group 2 }\end{array}$ & Value $t$ & $\boldsymbol{p}$ & $\begin{array}{l}\text { Devia. } \\
\text { Group } \\
\mathbf{1}\end{array}$ & $\begin{array}{l}\text { Devia. } \\
\text { Group } \\
\mathbf{2}\end{array}$ & $p$ Var. \\
\hline $\begin{array}{l}\text { CZS vs. } \\
\begin{array}{l}\text { PolS } \\
\text { CZS vs. }\end{array}\end{array}$ & 4.88 & 7.73 & -7.9532 & 0.0000 & 0.5553 & 0.9877 & 0.1013 \\
$\begin{array}{l}\text { SlovS } \\
\text { CZU vs. }\end{array}$ & 2.59 & 4.41 & 1.5509 & 0.1383 & 0.5553 & 0.7809 & 0.3243 \\
$\begin{array}{l}\text { PolU } \\
\text { CZU vs. }\end{array}$ & 2.59 & 3.11 & -4.9234 & 0.0001 & 0.3754 & 0.9011 & 0.0155 \\
$\begin{array}{l}\text { SlovU } \\
\text { CZN vs. }\end{array}$ & 92.53 & 88.14 & -3.6838 & 0.0017 & 0.3754 & 0.2078 & 0.0929 \\
$\begin{array}{l}\text { PolN } \\
\text { CZN vs. }\end{array}$ & 92.53 & 92.49 & 0.1112 & 0.9126 & 0.8353 & 0.7709 & 0.8148 \\
SlovN & & & & 0.0000 & 0.8353 & 1.8081 & 0.0310 \\
\hline
\end{tabular}

In other cases, the zero-hypothesis failed to be rejected, therefore we can claim that the use of telework in the category of sometimes in the Czech Republic and Slovakia is the same ( $p$-value 0.183 ). For the category of never, the data are very similar between the Czech Republic and Slovakia, as is documented by the $p$-value $(0.9126)$ and the graphical representation - the left box plot. The right box plot shows the difference between the use of TW in the Czech Republic and Poland in the category of sometimes.
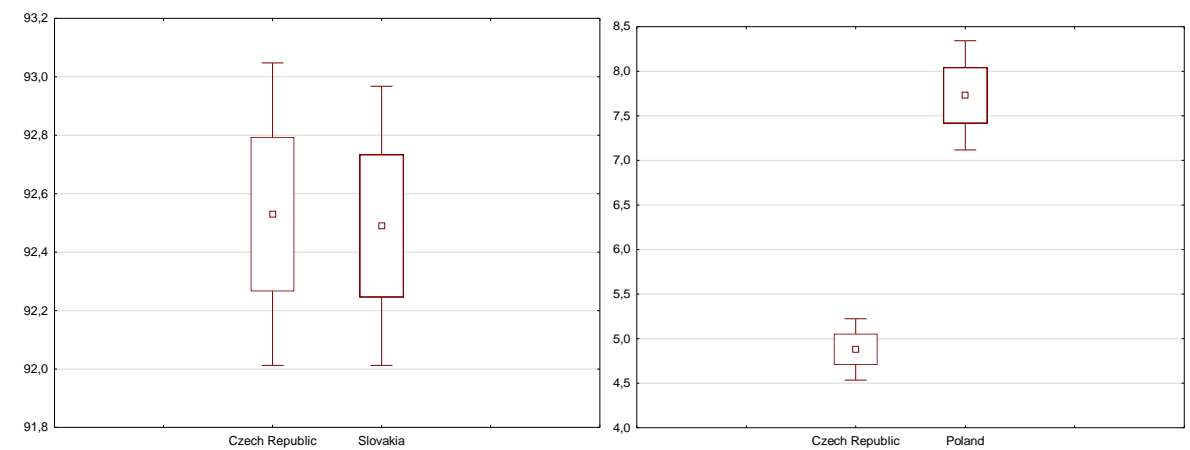

Fig. 1. Comparison of $\mathrm{CZ}$ and Slovakia men never using TW, Comparison of $\mathrm{CZ}$ and Poland men sometimes using TW.

The next comparison was related to the use of telework by women. As it is shown in Figure 2, the statistically significant differences between the Czech Republic and Poland were found in all categories, similar to those categories of the previous Figure. Comparing the Czech Republic and Slovakia, the zero hypothesis on the conformity 
of both samples was refuted in the category of sometimes (p-value 0.0000$)$ and never (p-value 0.0002) in favor of the alternative.

Table 2. Women comparison in Poland, Czech and Slovakia.

\begin{tabular}{llllllll}
\hline & $\begin{array}{l}\text { Mean } \\
\text { group 1 }\end{array}$ & $\begin{array}{l}\text { Mean } \\
\text { group 2 }\end{array}$ & Value $\boldsymbol{t}$ & $\boldsymbol{p}$ & $\begin{array}{l}\text { Devia. } \\
\text { Group } \\
\mathbf{1}\end{array}$ & $\begin{array}{l}\text { Devia. } \\
\text { Group } \\
\mathbf{2}\end{array}$ & $\boldsymbol{p}$ Var. \\
\hline $\begin{array}{l}\text { CZS vs. } \\
\begin{array}{l}\text { PolS } \\
\text { CZS vs. }\end{array}\end{array}$ & 3.56 & 9.22 & -25.312 & 0.0000 & 0.3306 & 0.6250 & 0.0715 \\
$\begin{array}{l}\text { SlovS } \\
\text { CZU vs. }\end{array}$ & 4 & 5.02 & -6.2828 & 0.0000 & 0.3306 & 0.6562 & 0.0534 \\
$\begin{array}{l}\text { PolU } \\
\text { CZU vs. }\end{array}$ & 4 & 4.78 & -3.1679 & 0.0053 & 0.4082 & 0.6629 & 0.1647 \\
$\begin{array}{l}\text { SlovU } \\
\text { CZN vs. }\end{array}$ & 92.44 & 85.99 & 15.058 & 0.0000 & 0.6883 & 1.1666 & 0.1318 \\
$\begin{array}{l}\text { PolN } \\
\text { CZN vs. }\end{array}$ & 92.44 & 91.01 & 4.7628 & 0.0005 & 0.6883 & 0.6539 & 0.8812 \\
SlovN & & & 0.0558 & 0.9561 & 0.4082 & 0.3928 & 0.9107 \\
\hline
\end{tabular}

In the category of women, there was a zero hypothesis ( $p$-value 0.9561 ). As it is shown in the left box plot both samples are very similar, and their mean values are 4, as well as maximum and minimum values. The right box plot compares the use of HW in the category of sometimes for Czech and Polish women.

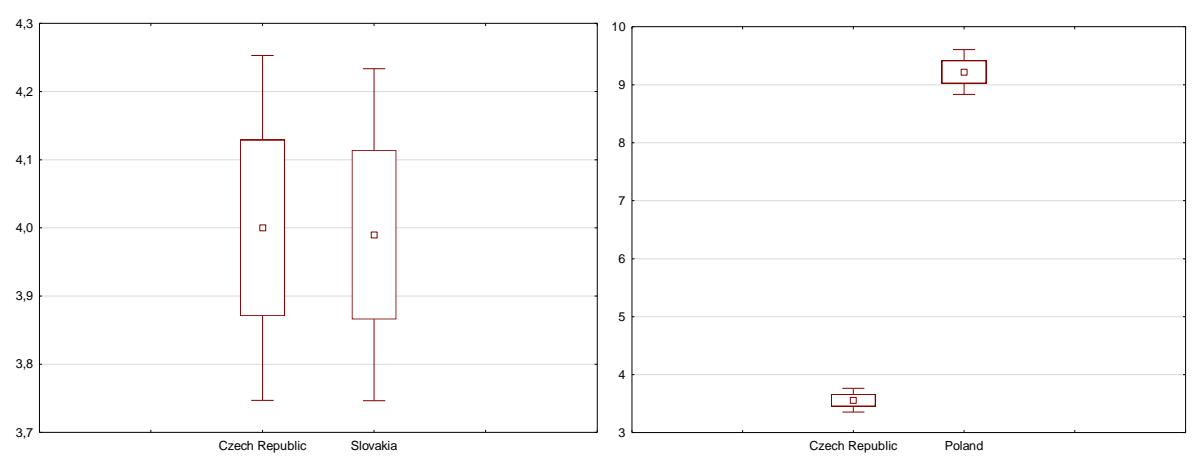

Fig. 2. Comparison of $\mathrm{CZ}$ and Slovakia women usually using TW, Comparison of CZ and Poland women sometimes using TW.

\section{Conclusion}

Telework statistics can be used for a range of analyzes It should be macroeconomic analysis, when we see telework as one of the factors of production, and it should be analysis of productivity, or competitiveness in a selected company. Analyzes of 
telework can also be carried out from the point of view of social aspects related to diverse ways of employing workers.

From the statistical analysis it is obvious that the use of telework in the Czech Republic and in Slovakia is relatively comparable. Both countries do not reach its use to such an extent as the average across the European Union. It should be noted that the use of telework within the European Union is highest in the Netherlands, Sweden and Germany [9].

In case of gender analysis, there are interesting differences between the use of telework for women and men in Poland and the Czech Republic and between Poland and Slovakia.

In practice, there are two basic telework models - complete (or almost complete) which is called "usually" and partial which is called sometimes. Many businesses that tested these models have concluded that when telework is complete that is that employees have moved away from the company, employees lose contact with the other colleagues and with current events. Therefore, it is preferable to choose partial telework when employees work for two or three days at home and the remaining days are at work.

From the statistical analysis results, it is evident that in the "men" category there is a significant difference in both telework models between Poland in comparison with the Czech Republic and Slovakia. There is no obvious difference between the Czech Republic and Slovakia in the frequency "sometimes".

In the "women" category, the results were very similar to the "men" category. Significant differences were found in both models in all three countries, only in the "usual" frequency when compared to the Czech Republic and Slovakia the difference was not statistically proven.

The differences in the use of telework can be given by the legislation when the Labor Code in the Czech Republic regulates very briefly this way of employment or by more demanding communication among colleagues, stricter discipline and bigger motivation and overall workforce on the employees' side.

\section{Acknowledgements. EF-IGS2017-Vrchota-IGS24B1}

\section{References}

1. Anderson, D. R., Sweeney, D. J., Williams, T. A., Camm, J. D., \& Cochran, J. J.: Statistics for Business \& Economics. 12th edn. OH: South-Western College Pub., Mason (2013).

2. Arvola, R., Tint, P., Kristjuhan, Ü. Employer attitude towards telework in real estate sector. In: Auzina, A. (eds.). Economic Science for Rural Development 2017, vol. 3, pp. 15-22, Latvian University of Agriculture, Jelgava (2017).

3. Bělina, M, Drápal, L. a kol.: Zákoník práce. Komentář. 2nd edn. C. H. Beck, Prague (2015).

4. Bělina, M. a kol.: Zákoník práce (EKZ). Komentár. 2nd edn. C.H.Beck, Prague. (2010).

5. Budíková, M., Králová, M., Maroš, B: Průvodce základními statistickými metodami. 1st edn. Grada Publishing, Prague (2010). 
6. Collins, A. M., Hislop, D., Cartwright, S.: Social support in the workplace between teleworkers, office-based colleagues and supervisors. New Technology Work and Employment. 31(2), 161-175 (2016).

7. Devore, J. L.: Probability and Statistics for Engineering and the Sciences. 9th edn. MA: Brooks Cole, Boston (2015).

8. Dooley, B.: At work away from work. The Psychologist 9(4), 155-158 (1996).

9. Eurostat: Employed persons working from home as a percentage of the total employment, by sex, age and professional status (\%), http://appsso.eurostat.ec.europa.eu/nui/show.do?dataset=lfsa_ehomp\&lang=en, last accessed 10/10/2017.

10. Freeman, J., Shoesmith, E., Sweeney, D., Anderson, D., Williams, T.: Statistics for Business and Economics. 4th edn. Cengage Learning EMEA, London (2017).

11. Freund, R. J., Wilson, W. J., Mohr, D. L.: Statistical methods. 3rd edn. Academic Press, Cambridge (2010).

12. Haddon, L. and Silverstone, R.: Teleworking in the 1990s: A View from Home. University of Sussex, Falmer (1993).

13. Korte, W. B., Kordey, N.: Telework in Europe. In: Rapp, B., Jackson P. (eds.) Organisation and Work Beyond 2000, pp. 287-299, Physica-Verlag Heidelberg, New York (2000).

14. Holloway, D.: Gender, Telework and the Reconfiguration of the Australian Family Home. Continuum 21(1), 33-44 (2007), DOI: 10.1080/10304310601103919.

15. Huws, U., Podro, S., Gunnarsson, E., Weijers, T., Arvanitaki, K., Trova, V.: Teleworking and Gender. 1st edn. Institute of Employment Studies, Brighton (1996).

16. Implementation of the European Framework Agreement on Telework: Report by the European Social Partners, https://resourcecentre.etuc.org/linked_files/documents/Framework\%20agreement $\% 20$ on\% 20telework\%20EN.pdf, last accessed 16/10/2017.

17. Meloun, M., Militký, J., Hill, M.: Statistická analýza vícerozměrných dat v př́kladech. 2nd edn. Academia, Praha (2012).

18. Nilles, J. M., Carlson, F. R., Gray, P., Hanneman, G. J. The Telecommunicationstransportations trade-off: options for tomorrow. 1 st edn. Wiley, New York (1976).

19. Michalík, D., Paleček, M.: Teleworking a jeho vnímání z pohledu zaměstnanců a managementu. Psychologie pro praxi 3/4 (December 2012), 89-95 (2012).

20. Silver, H.: Homework and domestic work. Sociological Forum 8(2), 181-204 (1993).

21. Sullivan, C.: What's in a Name? Definitions and Conceptualisations of Teleworking and Telework. New Technology, Work and Employment 18(3), 158-165 (2003).

22. Sullivan, C., Lewis, S.: Home-based Telework, Gender, and the Synchronization of Work and Family: Perspectives of Teleworkers and their Co-residents. Gender, Work \& Organization 8(2), 123-145 (2001), DOI: 10.1111/1468-0432.00125.

23. Walker, I.: Research Methods and Statistics. 1 st edn. Palgrave, London (2010). 